\title{
Removal of Heavy Metals from an Actual Small Scale Gold Mining Wastewater by Sorption onto Cocopeat
}

\author{
Jessie O. Samaniego ${ }^{1,2, *}$ and Maria Antonia N. Tanchuling ${ }^{2}$ \\ ${ }^{1}$ Department of Science and Technology - Philippine Nuclear Research Institute, Coomonwealth Ave., Quezon City, 1101, Philippines \\ ${ }^{2}$ Environmental Engineering Graduate Program, University of the Philippines Diliman, Quezon City, 1101, Philippines \\ *Corresponding author: josamaniego@pnri.dost.gov.ph
}

\section{KEYWORDS \\ Adsorption \\ Cocopeat \\ Heavy metals \\ SSGM \\ Wastewater}

\begin{abstract}
Cocopeat, a by-product of coconut husk, was used as adsorbent material to remove mercury $(\mathrm{Hg})$ and other heavy metals $(\mathrm{As}, \mathrm{Ba}, \mathrm{Cd}, \mathrm{Pb}$ ) from the wastewater gathered from the tailings collection tank of a ball mill facility at the small scale gold mining (SSGM) area in Camarines Norte province, Philippines. Batch sorption tests were carried out using actual wastewater samples with reduced suspended solids collected after $60 \mathrm{~min}$ of settling and without modifying the $\mathrm{pH}$ and other parameters to simulate the actual condition in the field. Batch tests of water samples with an initial pH of 7.30 and adsorbent dose of $1.0 \mathrm{~g}$ cocopeat/L were tested for Lagergren first-order, pseudo-second-order, intraparticle diffusion, and Freundlich models to evaluate kinetic parameters and adsorption isotherms. The removal efficiencies obtained for the heavy metals after the equilibrium time of 240 min were $97.14 \%, 94.74 \%, 10.00 \%, 66.67 \%$, and $27.01 \%$ for $\mathrm{Hg}$, As, Ba, Cd, and $\mathrm{Pb}$, respectively. The pseudo-second order kinetics model represented well the adsorption process as demonstrated with its higher correlation coefficients among the models.
\end{abstract}

(c) The Author(s) 2019. This article is distributed under a Creative Commons Attribution-ShareAlike 4.0 International license.

\section{INTRODUCTION}

Mercury and other heavy metals are present in the effluent and tailings from the SSGM ball mill facilities where the small scale miners use an amalgamation process with $\mathrm{Hg}$ to separate gold from mined ores. In 2000, the estimated consumption of $\mathrm{Hg}$ in the Philippines ranged from 20,000 to $30,000 \mathrm{~kg} / \mathrm{yr}$ (Israel and Asirot 2002), being used in various SSGM sites in the country, including in the small scale mining sites in Paracale, Camarines Norte, located $320 \mathrm{~km}$ south of Manila. In 2007, small scale miners in Camarines Norte use 10-25 g of Hg to recover $1 \mathrm{~g}$ of gold from the ores, which is higher than the world usage average of $1 \mathrm{~g} \mathrm{Hg}$ to recover $1 \mathrm{~g}$ of gold (Perez et al. 2007). These amounts of $\mathrm{Hg}$ together with other heavy metals are being released to the water bodies untreated as the inadequately designed sedimentation tanks serve as the only method for wastewater treatment. This practice becomes the basis of opposition to the amalgamation method because it affects the environment and human health (Israel and Asirot 2002; VelasquezLopez et al. 2010).

Mercury, which is one of the most toxic heavy metals released in the environment (Ahalya et al. 2003; Oboh et al. 2009), if present in rivers and lakes, it may be eaten by fish and in turn consumed by the people living in the area. Its major effects on human health include neurological and renal disturbances and impairment of pulmonary functions (Ahalya et al. 2003). Therefore, it is necessary to prevent $\mathrm{Hg}$ and other heavy metals from reaching water bodies such as creeks, rivers, and the sea. Several methods, such as reverse osmosis, electrodialysis, ultrafiltration, ion-exchange, chemical precipitation, and phytoremediation, are commonly used to remove heavy metals from mine tailings and other types of wastewater (Ahalya et al. 2003). These techniques were found to have disadvantages like incomplete metal removal, high reagent and energy requirements, and the generation of toxic sludges and other waste sludges that require careful disposal, all of which reduce its cost-effectiveness (Ahalya et al. 2003). Sorption of heavy metals on conventional adsorbents such as activated carbon have been widely used in many applications and found to be effective. Activated carbon, which is produced by carbonizing organic materials, is the most widely used adsorbent for wastewater treatment (Abdel Salam et al. 2011). However, this sorbent remains one of the expensive materials being used in removing heavy metals from wastewater (Abdel Salam et al. 2011; Kazemipour et al. 2008).

Agricultural waste is one of the rich sources of adsorbent due to its abundant availability (Abdel Salam et al. 2011). In the Philippines, one of the promising adsorbents from agricultural wastes is cocopeat. This material is a by-product of coconut husks during coconut fiber separation. Cocopeat consists mainly of lignin, cellulose, hemicellulose, and some pectin and extractives (mainly fat, fatty acids, fatty alcohols, phenols, terpenes, steroids, resin acids, rosin, and waxes) that promote adsorption of high metal ions (Conrad and Bruun Hansen 2007; Lee and Rowell 2004; Abad et al. 2002). Laboratory-scale column tests using cocopeat as an adsorbent with a bed volume of 110.0 $\mathrm{cm}^{3}$ removed $\mathrm{Pb}, \mathrm{Cu}$, and $\mathrm{Fe}$ from an aqueous solution (Ong 2010), while $\mathrm{Pb}$ and $\mathrm{Cd}$ were sorbed at bed capacities of 41 $\mathrm{mg} / \mathrm{g}$ and $28 \mathrm{mg} / \mathrm{g}$ of cocopeat, respectively (Amarasinghe 
2011). Batch tests using cocopeat in an aqueous solution showed high removal efficiencies on $\mathrm{Pb}$ and $\mathrm{Zn}$ at $\mathrm{pH} 4.0$ with an adsorbent dose of $1.0 \mathrm{~g} / \mathrm{L}$ (Waskita et al. 2012); 91\% at $\mathrm{pH} 4.5$ for $\mathrm{Zn}$ and $97 \%$ at $\mathrm{pH} 2.5$ for $\mathrm{Pb}$ with a dose of 20-22 g/L (Conrad and Bruun Hansen 2007); Pb at pH 4.0 with an adsorbent dose of $10 \mathrm{~g} / \mathrm{L}$ (Hazeri et al. 2012). Cocopeat biomass has also been used in the adsorption of $\mathrm{Pb}$, $\mathrm{Cd}, \mathrm{Cu}$, and $\mathrm{Ni}$ ions in a multi-component aqueous solution (Vijayaraghavan et al. 2016), while $\mathrm{Cu}, \mathrm{Ni}$, and $\mathrm{Zn}$ were removed by pretreatment modified cocopeat using nitric acid $\left(\mathrm{HNO}_{3}\right)$ and sodium hydroxide $(\mathrm{NaOH})$ (Diola and Orozco 2014; Einollahipeer and Pakzadtoochaei 2013).

Although an extensive number of sorption studies have been conducted in synthetic waters with spiked heavy metal concentrations, sorbed onto various adsorbents including cocopeat, the conclusions obtained from these studies can only be applied to actual wastewaters to a very limited extent. Using actual wastewater samples in adsorption experiments is necessary if the objective of the experiment is to assess the potential of certain sorbents in actual wastewater treatment. In this study, cocopeat is used as an adsorbent to treat $\mathrm{Hg}$ and other heavy metals (As, Ba, $\mathrm{Cd}$, and $\mathrm{Pb}$ ) present in the wastewater of SSGM ball mill facility. The objective of this study is to gain an initial understanding on the adsorption mechanisms by conducting laboratory batch experiments using actual SSGM wastewater that would lead to the design and development of an on-site treatment facility.

\section{MATERIALS AND METHODS}

\subsection{SSGM wastewater}

Actual wastewater gathered from an SSGM ball mill facility in Paracale, Camarines Norte, Philippines, was used as samples in the study. Wastewater samples were collected from the outlet of a tailings collection tank inside the facility and brought to the laboratory for $\mathrm{pH}$ and total suspended solids (TSS) analyses. Total suspended solids were measured using the gravimetric method and dried at $105^{\circ} \mathrm{C}$ while $\mathrm{pH}$ was measured using a digital $\mathrm{pH}-\mathrm{EC}-\mathrm{TDS}$ meter (Hanna HI 98130, USA). Separate water samples were collected and placed in 1,000-mL polypropylene bottles and were put in a container with ice to preserve the samples during transportation from the site to the laboratory for heavy metal analyses. The physico-chemical characteristics of actual SSGM wastewater are presented in Table 1.

\subsection{Plain settling}

Wastewater was poured into a glass column $(7.5 \mathrm{~cm}$ inside diameter and $120 \mathrm{~cm}$ high) for $60 \mathrm{~min}$ to reduce the suspended solids before analyzing its initial heavy metal concentrations. The optimum settling time was established

TABLE 1. Wastewater characteristics used in batch experiment.

\begin{tabular}{llccc}
\hline Parameter & Unit & $\begin{array}{c}\text { Actual SSGM } \\
\text { wastewater }\end{array}$ & $\begin{array}{c}\text { After 60 } \\
\text { min settling }\end{array}$ & \% reduction \\
\hline $\mathrm{pH}$ & $\mathrm{pH}$ & 6.88 & 7.30 & - \\
$\mathrm{TSS}$ & $\mathrm{g} / \mathrm{L}$ & 0.87 & 0.235 & 27.01 \\
$\mathrm{As}$ & $\mathrm{mg} / \mathrm{L}$ & 0.23 & 0.019 & 8.26 \\
$\mathrm{Ba}$ & $\mathrm{mg} / \mathrm{L}$ & 0.02 & 0.02 & 0.00 \\
$\mathrm{Cd}$ & $\mathrm{mg} / \mathrm{L}$ & 0.003 & 0.003 & 0.00 \\
$\mathrm{Hg}$ & $\mathrm{mg} / \mathrm{L}$ & 0.0906 & 0.0035 & 3.86 \\
$\mathrm{~Pb}$ & $\mathrm{mg} / \mathrm{L}$ & 1.27 & 0.137 & 10.79 \\
\hline
\end{tabular}

based on the results of a previous study that after $60 \mathrm{~min}$ of settling in the column, there were reductions of As (97.83\%), $\mathrm{Hg}$ (95.14\%), and $\mathrm{Pb}$ (93.70\%) from the actual SSGM wastewater samples (Samaniego and Tanchuling 2018). After settling, water samples were analyzed for heavy metal and TSS concentrations to determine the reduction rate after $60 \mathrm{~min}$. Settling resulted in a reduction of $27.01 \%$ on TSS, $8.26 \%$ on $\mathrm{As}, 10.79 \%$ on $\mathrm{Pb}$, and $3.86 \%$ on $\mathrm{Hg}$ concentrations compared with their respective initial concentrations, while there were no concentration reductions observed on $\mathrm{Ba}$ and Cd (Table 1). Water samples collected from the settling column after 60 min were used samples for batch adsorption tests.

\subsection{Analytical methods}

Heavy metal analyses used an Atomic Absorption Spectrophotometer (Agilent 55AA, USA) and followed the appropriate methods suggested in Standard Methods for the Examination of Water and Wastewater (Clescerl et al. 1998). Hydride generation AAS was used for As, flame AAS for Ba, $\mathrm{Cd}$, and $\mathrm{Pb}$, and cold vapor AAS for $\mathrm{Hg}$. The limit of detection for the method used in analyzing the metals was $0.001 \mathrm{mg} / \mathrm{L}$ for As, $0.2 \mathrm{mg} / \mathrm{L}$ for $\mathrm{Ba}, 0.003 \mathrm{mg} / \mathrm{L}$ for $\mathrm{Cd}$, $0.01 \mathrm{mg} / \mathrm{L}$ for $\mathrm{Pb}$, and $0.0001 \mathrm{mg} / \mathrm{L}$ for $\mathrm{Hg}$.

\subsection{Cocopeat batch adsorption tests}

\subsubsection{Characterization and preparation of cocopeat}

The cocopeat used as the adsorbent in this study was sourced from the stockpiles of Soriano Integrated Fiber Corporation coconut husk decorticating plant in Sariaya, Quezon Province. The same cocopeat was also used as the adsorbent in a number of previous studies on batch and column experiments to remove heavy metals from an aqueous solution (Ong 2010; Parcon 2010; Pingul 2010). Most of the physico-chemical characteristics of cocopeat assessed in the previous studies of Ong (2010), Parcon (2010), and Aquino et al. (2009) were also assessed in this study, in addition to several other important parameters such as bulk density, porosity, particle size and heavy metal contents unique to the present study.

Particle size distribution analysis was performed by following the procedures stated in ASTM D422-63. Cocopeat samples were sorted using Test Sieve No. 10 (W.S. Tyler, USA) to get a particle size of $\leq 2 \mathrm{~mm}$ and to eliminate long fibers and impurities. The sorted cocopeat was mixed to come up with a homogenous sample to be used in the

TABLE 2. Physical characteristics and heavy metal concentrations of the cocopeat used in the experiment.

\begin{tabular}{ll}
\hline Parameter & Value \\
\hline Moisture Content (\%) & 38.28 \\
Bulk Density, $\rho_{\mathrm{b}}\left(\mathrm{g} / \mathrm{cm}^{3}\right)$ & 0.101 \\
Particle Density $\left(\mathrm{g} / \mathrm{cm}^{3}\right)$ & 1.56 \\
Porosity, $\mathrm{n}(\%)$ & 93.46 \\
Particle Size (mesh) & $0.075-2 \mathrm{~mm}$ \\
Saturated hydraulic conductivity, $\mathrm{K}_{\mathrm{s}}(\mathrm{cm} / \mathrm{hr})$ & 70.04 \\
Arsenic $(\mathrm{mg} / \mathrm{L})$ & $\mathrm{N} . D$. \\
Barium $(\mathrm{mg} / \mathrm{L})$ & N.D. \\
Cadmium $(\mathrm{mg} / \mathrm{L})$ & N.D. \\
Mercury $(\mathrm{mg} / \mathrm{L})$ & 0.208 \\
Lead $(\mathrm{mg} / \mathrm{L})$ & N.D. \\
\hline
\end{tabular}


experiment and maintained its natural condition without washing or any chemical pre-treatment. The aforementioned technique was chosen to test the material under the simplest and most practical operational conditions, which may be adopted later on by the small scale gold mining processors. A summary of the physical characteristics and heavy metal concentrations of the cocopeat used in the experiment is presented in Table 2.

\subsubsection{Batch tests}

Batch tests were carried out using the collected wastewater samples after $60 \mathrm{~min}$ of settling in a glass column. The measured $\mathrm{pH}$ of the entire wastewater samples was 7.30. Tests were conducted by mixing $100 \mathrm{~mL}$ wastewater with a $1.0 \mathrm{~g} / \mathrm{L}$ adsorbent dose in a $250 \mathrm{~mL}$ Erlenmeyer flask. The flask with the solution was placed in an orbital shaker (Estuart SSL1 Orbital Platform Shaker, UK) set at a constant agitation speed of $200 \mathrm{rpm}$ and withdrawn after the specified contact times of 10,30,60, 120, 180, 240, 360, and 540 min for $\mathrm{As}, \mathrm{Pb}$, and $\mathrm{Hg}$, and 10, 30, 60, 120, 180, and 240 min for $\mathrm{Cd}$ and $\mathrm{Ba}$. After mixing in an orbital shaker, the solution was filtered using Whatman \#40 (USA) filter paper placed in a glass funnel. The Erlenmeyer flasks were washed with deionized water to remove cocopeat particles and heavy metal ions that may have been retained in the flask. Washed water was also filtered and mixed with filtrate. The collected filtrates were acidified by adding $\mathrm{HNO}_{3}$ until their $\mathrm{pH}$ reached $<2$. The samples were transferred into polyethylene sampling bottles and refrigerates and preserved for heavy metal analyses.

Adsorption of heavy metals using $0.10 \mathrm{~g}$ of cocopeat in $100 \mathrm{~mL}$ of wastewater was carried out in this study. Mixtures were agitated at $200 \mathrm{rpm}$ in a shaker for $240 \mathrm{~min}$, which was more than the ample time for adsorption equilibrium. The metal uptake $q_{t}$ at time $t$ was computed using Equation 1.

$$
q_{t}=\frac{\left(C_{i}-C_{t}\right) V}{W}
$$

where $C_{i}$ is the initial metal concentration $(\mathrm{mg} / \mathrm{L}), C_{t}$ is the metal concentration at time $t(\mathrm{mg} / \mathrm{L}), \mathrm{V}$ is the volume of metal solution used (L), $\mathrm{W}$ is the weight of adsorbent $(\mathrm{g})$, and $q_{t}$ is the amount of metal adsorbed at a given time $t$ (mg heavy metal/g adsorbent).

\subsubsection{Kinetic modelling}

To identify the rate-controlling mechanisms during the adsorption of $\mathrm{As}, \mathrm{Ba}, \mathrm{Cd}, \mathrm{Hg}$ and $\mathrm{Pb}$, the following steps were considered, as described by Benavente et al. (2011); (1) mass transfer of the metal ions from the wastewater to the cocopeat surface, (2) adsorption of the metal ions onto sites, and (3) intra-particle diffusion of the metal ions onto cocopeat. For this purpose, simplified models were applied to evaluate the experimental batch data for each metal: a Lagergren first-order equation, a pseudo-second-order equation, and intra-particle diffusion.

The pseudo-first-order or Lagergren rate equation was the first rate equation for sorption in a liquid/solid system based on solid capacity, expressed with Equation 2

$$
\frac{d q_{t}}{d t}=k_{1}\left(q_{e}-q_{t}\right)
$$

where $q_{e}$ and $q_{\mathrm{t}}$ are the sorption capacities $(\mu \mathrm{g} / \mathrm{g})$ at equilibrium and at time $t$, respectively, and $k_{1}$ is a pseudo-first- order sorption rate constant $(1 / \mathrm{min})$. By integration, assuming the boundary condition $q_{t}=0$ at $t=0$ and $q_{t}=q_{t}$ at $t=t$, the equation becomes that show in Equation 3 .

$$
\log \left(q_{e}-q_{t}\right)=\log q_{e}-\frac{k_{1}}{2.303} t
$$

where $k_{1}(1 / \mathrm{min})$ is calculated by plotting the function.

If the rate of adsorption has a second-order mechanism, the pseudo-second-order chemisorption kinetic rate equation is expressed by Equation 4 (Ho and Mckay 2000).

$$
\frac{d_{q}}{d_{t}}=k_{2}\left(q_{e}-q_{t}\right)^{2}
$$

where $k_{2}$ is the pseudo-second-order sorption rate constant $(\mathrm{g} /(\mu \mathrm{g} \mathrm{min}))$. Integration of Equation 4 , assuming the boundary conditions $q_{t}=0$ at $t=0$ and $q_{t}=q_{t}$ at $t=t$, yields (Equation 5):

$$
\frac{t}{q_{t}}=\frac{1}{k_{2} q_{e}^{2}}+\frac{1}{q_{e}} t
$$

where $q_{t}$ is the amount of sorption ( $\left.\mu \mathrm{g} / \mathrm{g}\right)$ at time (min), $q_{e}$ is the amount of sorption at equilibrium time $(\mu \mathrm{g} / \mathrm{g})$, and $k_{2}$ $(\mathrm{g} /(\mu \mathrm{g} \mathrm{min}))$ is calculated by plotting the function.

The intra-particle diffusion model in this study was explored using the Weber-Morris equation (Equation 6), as described by Kaczala et al. (2009).

$$
q_{t}=k_{i} t^{\frac{1}{2}}+c
$$

where $q_{t}$ is the amount adsorbed at time $t(\mu \mathrm{g} / \mathrm{g}), t$ is the contact time (min), $k_{i}$ is the intra-particle diffusion rate constant $\left(\mu \mathrm{g} /\left(\mathrm{g} \min ^{1 / 2}\right)\right)$, and $k_{i}$ and $c$ are calculated by plotting the function.

\subsubsection{Freundlich isotherm equation}

The Freundlich equation is an empirical relationship describing the adsorption of solutes from a liquid to a solid surface. It gives an expression encompassing the surface heterogeneity and the exponential distribution of active sites and their energies (Abdel Salam et al. 2011). The Freundlich model was applied since this model is considered suitable, particularly for low to intermediate concentration ranges (Kaczala et al. 2009). The general form of this model is (Equation 7):

$$
q_{e}=K_{F} C_{e}^{\frac{1}{n}}
$$

Equation 7 can be linearized by taking the logarithm of both sides of the equation and will result in Equation 8.

$$
\log q_{e}=\log K_{F}+\frac{1}{n} \log C_{e}
$$

where $C_{e}$ is the equilibrium concentration $(\mu \mathrm{g} / \mathrm{g}), q_{e}$ is the adsorbed amount at equilibrium $(\mu \mathrm{g} / \mathrm{g})$, and $\mathrm{K}_{\mathrm{F}}$ and $\frac{1}{n}$ are the Freundlich constants. $K_{\mathrm{F}}$ and $\frac{1}{n}$ are experimentally calculated by plotting the function.

\section{RESULTS AND DISCUSSION}

The present study did not analyze the effect of $\mathrm{pH}$ on adsorption efficiency because its objective was to apply a filter 
bed adsorption system using cocopeat to the SSGM ball mill facility without any adjustment in $\mathrm{pH}$ and other physicochemical properties of the wastewater. Furthermore, only an adsorbent dose of $1.0 \mathrm{~g}$ cocopeat/L was used in the experiment because applying a higher dosage resulted in adsorption of more ions or complete sorption of ions from the sorbate. The room temperature during batch tests ranged from 25 to $27^{\circ} \mathrm{C}$

\section{1 $\mathrm{pH}$ development during adsorption}

During the batch adsorption test, $\mathrm{pH}$ development was monitored with respect to contact time. With an initial $\mathrm{pH}$ of 7.30, it decreased to $\mathrm{pH} 7.15$ in the first 10 min but then went up to $\mathrm{pH} 7.79$ after 240 min of contact time (Figure 1). The initial decrease of $\mathrm{pH}$ observed conforms with the study conducted by Kaczala et al. (2009) on the adsorption of $\mathrm{Pb}$ onto sawdust. Such an increase of hydrogen ions might be related to deprotonation of acidic groups present in lignin, as pointed out by Ho and Mckay (2000) during the sorption of Pb onto lignin-based fern tree adsorbent. Such observations were also observed in the present study.

\subsection{Removal efficiency}

The removal efficiency obtained for the heavy metals with the initial $\mathrm{pH}$ of 7.30 at a $1.0 \mathrm{~g} / \mathrm{L}$ adsorbent dose after 240 min is shown in Figure 2. The highest removal efficiency was achieved by $\mathrm{Hg}(97.14 \%)$, followed by As $(94.74 \%)$, Cd (66.67\%), $\mathrm{Pb}(27.01 \%)$, and $\mathrm{Ba}(10.00 \%)$. High removal efficiencies can be attributed to low initial concentrations of heavy metal adsorbed, as demonstrated in the efficiency of $\mathrm{Hg}$ and its low initial concentration, while a low removal efficiency was found with $\mathrm{Pb}$, which had a high initial concentration. As presented in Figure 2, the order from the highest removal efficiency $(\mathrm{Hg}>\mathrm{As}>\mathrm{Cd}>\mathrm{Pb}>\mathrm{Ba})$ is inversely related to the sequence from highest to lowest initial concentrations of wastewater used in the experiment $(\mathrm{Pb}>\mathrm{Ba}>\mathrm{As}>\mathrm{Cd}>\mathrm{Hg})$. The varied range of initial concentra-

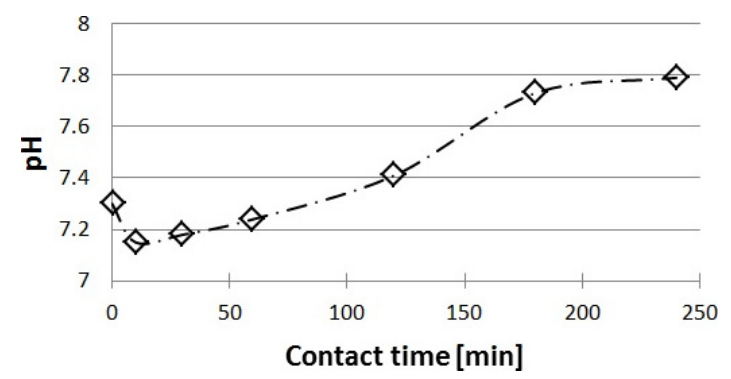

FIGURE 1. pH development over time during batch tests using $1.0 \mathrm{~g}$ cocopeat/L.

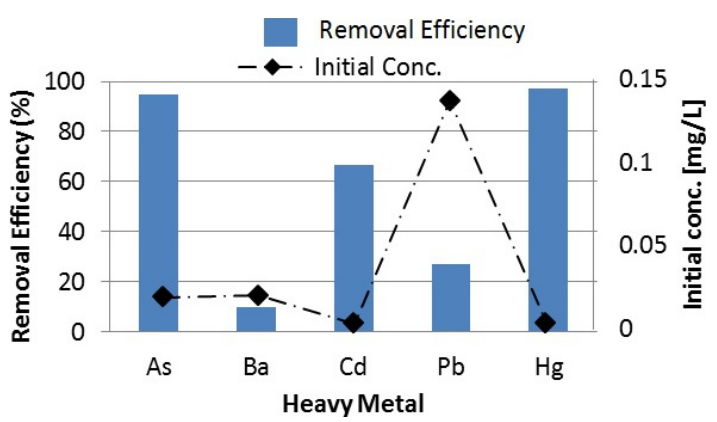

FIGURE 2. Removal efficiency (\%) and initial concentration for heavy metals at $t=240 \mathrm{~min}$ with $1.0 \mathrm{~g} / \mathrm{L}$ adsorbent dose. tions of different heavy metals present in the actual SSGM wastewater is traced from the composition of mined ores while $\mathrm{Hg}$ concentration in wastewater was directly related to the use of $\mathrm{Hg}$ in amalgamation. The longer time required to attain the equilibrium ( $240 \mathrm{~min}$ ) in this study is probably related to the complexity of the actual wastewater tested, where different organic and inorganic compounds compete for sorptive sites, compared with the spiked synthetic water used in previous studies with cocopeat (Waskita et al. 2012; Conrad and Bruun Hansen 2007; Hazeri et al. 2012).

\subsection{Effect of contact time}

Effect of contact time on $\mathrm{As}, \mathrm{Ba}, \mathrm{Cd}, \mathrm{Hg}$, and $\mathrm{Pb}$ uptake rate by cocopeat with an initial $\mathrm{pH}$ of 7.30 are shown in Figures 3a-e. At an adsorbent dose of $1.0 \mathrm{~g}$ cocopeat/L, the concentrations on solid phase were increased until reaching their respective equilibrium concentrations. The solid phase concentrations for $\mathrm{As}, \mathrm{Ba}, \mathrm{Cd}$, and $\mathrm{Hg}$ were erratic in the first $120 \mathrm{~min}$, but at $180 \mathrm{~min}$, the cocopeat adsorption reached its equilibrium. At the first $120 \mathrm{~min}$, the liquid phase concentration of $\mathrm{Pb}$ increased (Figure 3e), resulting in a higher negative reduction for the solid phase. At 180 $\mathrm{min}$, the solid phase concentration for $\mathrm{Pb}$ on cocopeat increased, but it was still low at the end of $240 \mathrm{~min}$, and by prolonging the contact time, there were no more changes observed in the adsorption.

In this study, longer contact time (from 240 to 540 $\mathrm{min}$ ) for $\mathrm{As}, \mathrm{Hg}$, and $\mathrm{Pb}$ to attain equilibrium was probably related to the complexity of the mining wastewater tested, where different organic and inorganic compounds compete for sorptive sites (Kaczala et al. 2009), compared with the heavy metal-spiked distilled water used in previous studies with cocopeat (Ong 2010; Parcon 2010; Pingul 2010; Waskita et al. 2012).

\subsection{Kinetic modelling}

\subsubsection{Lagergren first-order model}

The resulting parameters from the linearized adsorption data of the kinetic batch experiment to Lagergren firstorder model for $\mathrm{As}, \mathrm{Ba}, \mathrm{Cd}, \mathrm{Hg}$, and $\mathrm{Pb}$ with an initial $\mathrm{pH}$

TABLE 3. Lagergren first-order parameters for heavy metals adsorption onto cocopeat.

\begin{tabular}{lccccc}
\hline $\begin{array}{l}\text { Adsorbent } \\
(1.0 \mathrm{~g} / \mathrm{L})\end{array}$ & $\begin{array}{c}k_{1} \\
(1 / \mathrm{min})\end{array}$ & $\begin{array}{c}q_{\exp } \\
(\mu \mathrm{g} / \mathrm{g})\end{array}$ & $\begin{array}{c}q_{\text {calc }} \\
(\mu \mathrm{g} / \mathrm{g})\end{array}$ & $\begin{array}{c}\text { Deviation } \\
(\%)\end{array}$ & $R^{2}$ \\
\hline $\mathrm{As}$ & 0.0041 & 18.00 & 5.45 & 69.72 & 0.6525 \\
$\mathrm{Ba}$ & 0.0016 & 2.00 & 1.34 & 33.00 & 0.2753 \\
$\mathrm{Cd}$ & 0.0032 & 2.00 & 1.58 & 21.00 & 0.3019 \\
$\mathrm{Hg}$ & 0.0039 & 3.41 & 0.23 & 93.25 & 0.0729 \\
$\mathrm{~Pb}$ & 0.0053 & 57.00 & 45.39 & 20.37 & 0.2049 \\
\hline
\end{tabular}

TABLE 4. Pseudo second-order parameters for heavy metal adsorption onto cocopeat.

\begin{tabular}{llrrrr}
\hline $\begin{array}{l}\text { Adsorbent } \\
(1.0 \mathrm{~g} / \mathrm{L})\end{array}$ & $\begin{array}{c}k_{1} \\
(\mathrm{~g} /(\mu \mathrm{g} \min ))\end{array}$ & $\begin{array}{c}q_{\exp } \\
(\mu \mathrm{g} / \mathrm{g})\end{array}$ & $\begin{array}{c}q_{\text {calc }} \\
(\mu \mathrm{g} / \mathrm{g})\end{array}$ & $\begin{array}{c}\text { Deviation } \\
(\%)\end{array}$ & $R^{2}$ \\
\hline $\mathrm{As}$ & 0.0023 & 18.00 & 18.98 & 5.16 & 0.9924 \\
$\mathrm{Ba}$ & 0.0125 & 2.00 & 2.13 & 6.10 & 0.7463 \\
$\mathrm{Cd}$ & -0.0502 & 2.00 & 1.83 & 8.50 & 0.9559 \\
$\mathrm{Hg}$ & 1.3551 & 3.41 & 3.66 & 6.83 & 0.9410 \\
$\mathrm{~Pb}$ & -0.0000155 & 57.00 & 6.05 & 89.38 & 0.7358 \\
\hline
\end{tabular}




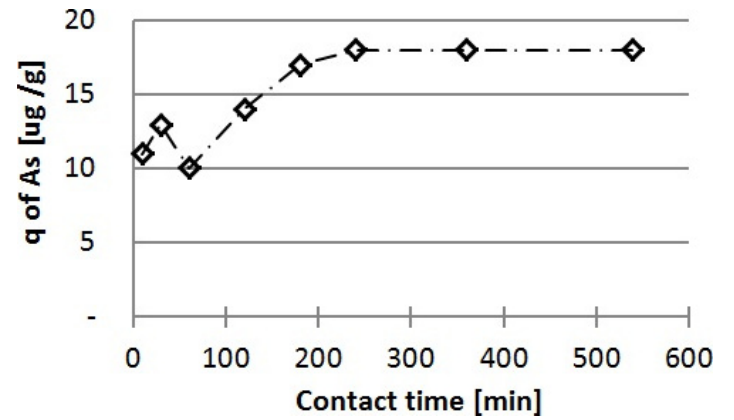

(a)

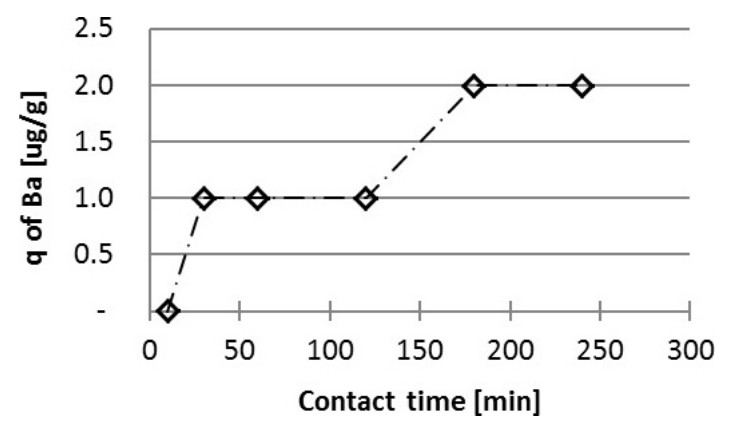

(b)

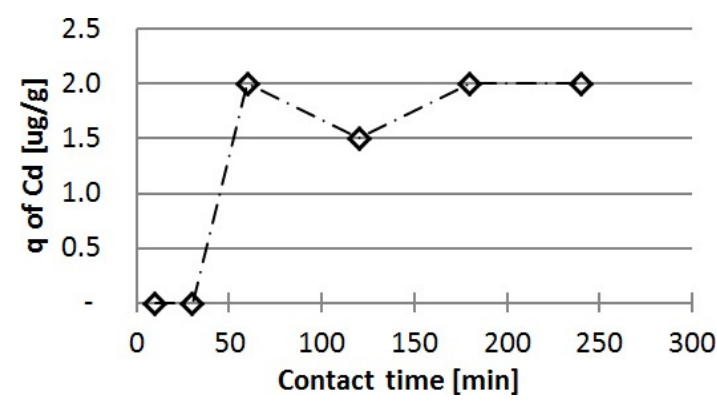

(c)

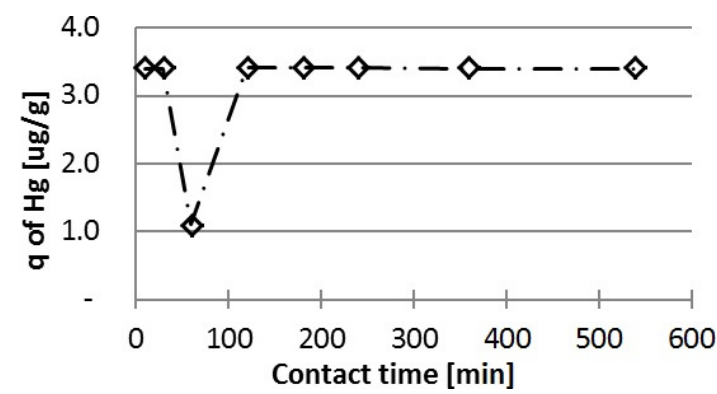

(d)

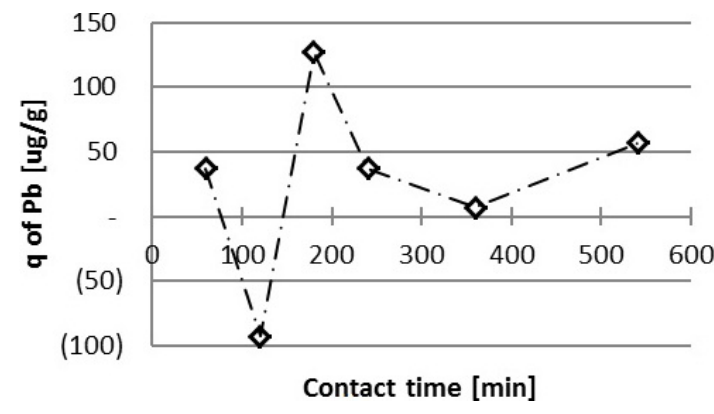

(e)

FIGURE 3. Effect of contact time on As (a), Ba (b), Cd (c), $\mathrm{Hg}$ (d), and Pb (e) uptake rate by cocopeat with initial $\mathrm{pH}$ of 7.30 and adsorbent dose of 1.0 g/L. of 7.30 at an adsorbent dose of $1.0 \mathrm{~g} / \mathrm{L}$ are presented in Table 3. All heavy metals tested did not fit well with low computed linear regression correlations $\mathrm{R}^{2}$ ranging from 0.0729 to 0.6525 . This suggests that the first-order model cannot be considered as the sorption process of heavy metals onto cocopeat.

\subsubsection{Pseudo-second order model}

The results of pseudo-second order adsorption for the heavy metals onto cocopeat are shown in Table 4 . The correlation coefficients for the second-order kinetics model $\left(\mathrm{R}^{2}\right)$ are higher compared with those of the first-order equation, indicating the applicability of this kinetic equation and the second-order nature of the adsorption process of heavy metals onto cocopeat. In addition to the high $R^{2}$ values, the theoretical and experimental values of $q_{e}$ obtained low percentages of deviation, suggesting that pseudo-secondorder kinetics can be considered as the sorption process of heavy metals onto cocopeat.

In the case of $\mathrm{Pb}$, the $q_{\exp }(57.00 \mu \mathrm{g} / \mathrm{g})$ is high compared with the $q_{\text {calc }}(6.05 \mu \mathrm{g} / \mathrm{g})$, which is due to the complexity of the actual wastewater used in the experiment, as shown in Figure 3e. Although it presents a very high deviation, it can still be considered and fitted to the pseudo second-order model as it has a higher $\mathrm{R}^{2}$ value than the first-order model. Negative (-) $k_{2}$ values for $\mathrm{Cd}(-0.0502 \mathrm{~g} /(\mu \mathrm{g} \min ))$ and $\mathrm{Pb}(-$ $0.0000155 \mathrm{~g} /(\mu \mathrm{g} \mathrm{min}))$ are attributed to the rapid uptake followed by desorption in the first $120 \mathrm{~min}$, as illustrated in Figure 3e. The pseudo-second order model can be considered a kinetics model based on the assumption that the rate limiting step may be a chemical adsorption (chemisorption) as it provides a correlation of the data.

\subsubsection{Intra-particle diffusion model}

The linearity of the curve for the intra-particle diffusion model had a wide range of $R^{2}$, between 0.0454 and 0.8394 (Table 5). These indicate that the linearity may not be the basis for the selection of the rate limiting step of heavy metal adsorption onto cocopeat. The rate constants $\left(k_{i}\right)$ characteristic of the adsorption in the region where intraparticle diffusion is rate controlling. Based on the linear plots from the origin $(y$-intercept other than 0$)$ indicates that there are other sorption steps such as external diffusion (Kaczala et al. 2009).

In summary, among the three kinetic models evaluated in this study, the pseudo-second order kinetics model represented well the adsorption process, as demonstrated with its higher correlation coefficients, $\mathrm{R}^{2}$ values in all heavy metals compared with the pseudo-first order and intra-particle diffusion models. The applicability of pseudo-second order kinetics suggests that the rate limiting step may be a chemical adsorption or chemisorption as the sorption process of heavy metals onto cocopeat. This result is in accordance with the sorption process of heavy

TABLE 5. Kinetic parameters of heavy metal intra-particle diffusion onto cocopeat.

\begin{tabular}{lccc}
\hline Adsorbent $(1.0 \mathrm{~g} / \mathrm{L})$ & $\mathrm{k}_{\mathrm{i}}\left(\mathrm{g} /\left(\mu \mathrm{g} \mathrm{min}^{1 / 2}\right)\right)$ & $c($ Intercept $)$ & $R^{2}$ \\
\hline $\mathrm{As}$ & 0.4234 & 9.664 & 0.7654 \\
$\mathrm{Ba}$ & 0.1453 & -0.1953 & 0.8394 \\
$\mathrm{Cd}$ & 0.1724 & -0.3664 & 0.6872 \\
$\mathrm{Hg}$ & 0.0321 & 2.7217 & 0.0726 \\
$\mathrm{~Pb}$ & 2.7509 & -12.515 & 0.0454 \\
\hline
\end{tabular}




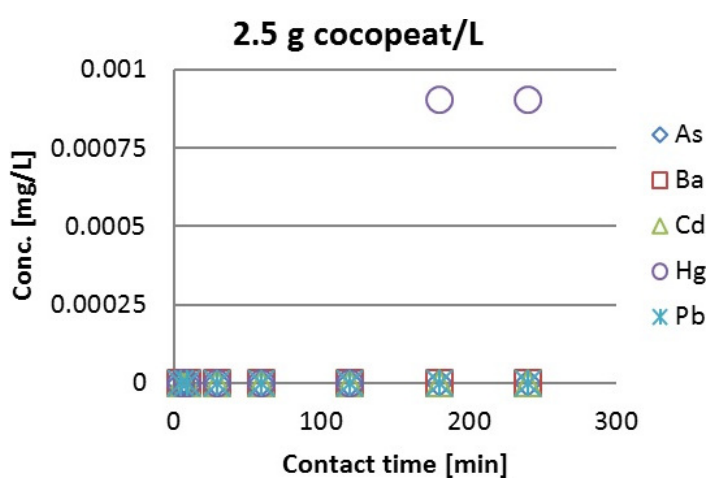

(a)

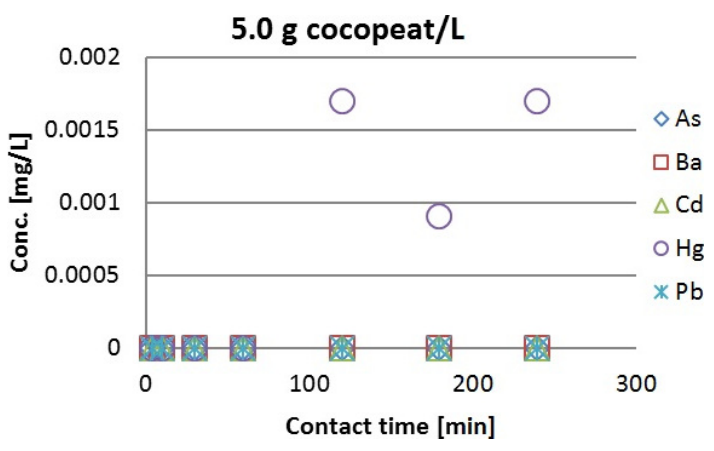

(b)

FIGURE 4. Sorbate concentration after batch test using $2.5 \mathrm{~g}$ cocopeat/L (a) and 5.0 g cocopeat/L (b)

metals onto cocopeat using synthetic water in the studies of Ong (2010) and Waskita et al. (2012).

\subsection{Adsorption isotherm}

The batch experiment performed in this study used an adsorbent dose of $1.0 \mathrm{~g}$ cocopeat/L of sorbate at an initial $\mathrm{pH}$ of 7.30 and temperature range of $25-27^{\circ} \mathrm{C}$. In an attempt to determine the Freundlich constants, additional batch tests using higher adsorbent doses (2.5 g cocopeat/L and 5.0 $\mathrm{g}$ cocopeat/L) were performed to determine the $\mathrm{K}_{\mathrm{F}}$ and $1 / n$ of each heavy metal. After the batch tests, the results showed that all of the heavy metals except for Hg had concentrations that were below the detection limits of the AAS used for the heavy metal analyses, as shown in Figures 4ab. The increase in $\mathrm{Hg}$ concentration in the effluent after $180 \mathrm{~min}(2.5 \mathrm{~g}$ cocopeat/L) and $120 \mathrm{~min}$ (5.0 g cocopeat/L) was caused by the desorption of $\mathrm{Hg}$ ions present in the cocopeat, and which had an initial concentration of 0.208 $\mathrm{mg} / \mathrm{kg}$

Considering the results of the batch tests with high adsorbent doses, the calculation of $K_{F}$ and $1 / n$ constants from the adsorption equilibrium of $\mathrm{As}, \mathrm{Ba}, \mathrm{Cd}$, and $\mathrm{Pb}$ becomes impossible due to the absence of the trend in the results, thus no $q_{e}$ and $C_{e}$ were accepted. In the case of $\mathrm{Hg}$, the increase in the sorbate concentration after $120 \mathrm{~min}$ caused by desorption may cause an unfavorable sorption intensity if used to calculate the $K_{F}$ and $1 / n$ constants.

\section{CONCLUSIONS}

In the present study, wastewater collected from the ball mill facility of a small scale gold mining site is characterized with a high concentration of $\mathrm{Hg}$ and other heavy metals, as well as suspended solids. Untreated cocopeat was used as an adsorbent in batch tests and demonstrated a capability to reduce heavy metals from actual SSGM wastewater that is complex in nature. Batch adsorption experiments were carried out using actual wastewater samples with reduced suspended solids collected after 60 min of settling and without modifying the $\mathrm{pH}(\mathrm{pH} 7.30)$ and other parameters to simulate the actual conditions in the field. The settling process prior to sorption was proven to be an important step concerning the treatment of wastewater containing heavy metals.

After an equilibrium time of $240 \mathrm{~min}$, batch tests with an adsorbent dose of $1.0 \mathrm{~g}$ cocopeat/L resulted in high removal efficiencies for $\mathrm{Hg}$ (97.14\%), followed by As (94.74\%), $\mathrm{Cd}(66.67 \%), \mathrm{Pb}$ (27.01\%), and $\mathrm{Ba}$ (10.00\%). High removal efficiencies can be attributed to low initial concentrations of heavy metals adsorbed, as demonstrated in the efficiency of $\mathrm{Hg}$ and its low initial concentration. This is probably related to the complexity of the actual wastewater tested, where different organic and inorganic compounds compete for sorptive sites, compared with the spiked synthetic water used in previous studies with cocopeat.

Among the three kinetic models evaluated in this study, the pseudo-second order kinetics model best represented the adsorption process, as shown in its higher correlation coefficients $\left(\mathrm{R}^{2}\right)$. The applicability of pseudo-second-order kinetics suggests that the rate limiting step may be a chemical adsorption or chemisorption as the sorption process of heavy metals onto cocopeat.

\section{ACKNOWLEDGMENTS}

The authors acknowledge the Department of Science and Technology-Philippine Council for Industry, Energy and Emerging Technology Research and Development (DOSTPCIEERD) for funding the project and special credit to the Department of Science and Technology - Engineering Research and Development for Technology (DOST-ERDT) for the scholarship grants and research fund.

\section{REFERENCES}

Abad M, Noguera P, Puchades R, Maquieira A, Noguera V. 2002. Physico-chemical and chemical properties of some coconut coir dusts for use as a peat substitute for containerised ornamental plants. Bioresour Technol. 82(3):241-245. doi:10.1016/S0960-8524(01)00189-4.

Abdel Salam OE, Reiad NA, ElShafei MM. 2011. A study of the removal characteristics of heavy metals from wastewater by low-cost adsorbents. J Adv Res. 2(4):297-303. doi:10.1016/j.jare.2011.01.00.

Ahalya N, Ramachandra T, Kanamadi R. 2003. Biosorption of heavy metals. Res J Chem Environ. 7(4):71-79. http: //wgbis.ces.iisc.ernet.in/energy/water/paper/bio sorption/biosorption.htm.

Amarasinghe B. 2011. Lead and cadmium removal from aqueous medium using coir pith as adsorbent: batch and fixed bed column studies. J Trop For Environ. 1(1):36-47. doi:10.31357/jtfe.v1i1.82.

Aquino D, Tanchuling M, Fontanilla L. 2009. Effect of flow rates in the removal of lead ions from solution in a coco peat column. Proceedings of the 3rd Engineering Research and Development for Technology (ERDT) Conference; Mandaluyong City, Philippines. p. 82-85. http://koha.nlp.gov.ph/cgi-bin/koha/opac-ISBDde tail.pl?bib=766997.

Benavente M, Moreno L, Martinez J. 2011. Sorption of heavy metals from gold mining wastewater using chitosan. J Taiwan Inst Chem Eng. 42:976-988. doi:10.1016/j.jtice. 2011.05.003. 
Clescerl LS, Greenberg AE, Eaton AD, editors. 1998. Standard methods for the examination of water and wastewater. 20th edition. Maryland: American Public Health Association.

Conrad K, Bruun Hansen H. 2007. Sorption of zinc and lead on coir. Bioresour Technol. 98(1):89-97. doi:10.1016/j.bi ortech.2005.11.018.

Diola M, Orozco C. 2014. Improved removal of copper ions from aqueous solution using $\mathrm{NaOH}$-pretreated coco peat. ASEAN Eng J Part C. 4(1):93-103. http://seed - net.org/wp-content/uploads/2015/12/IMPROVED - REMOVAL-OF-COPPER-IONS-FROM-AQUEOUS-S OLUTION-USING-NaOH-PRETREATED-COCO-PEA T.pdf.

Einollahipeer F, Pakzadtoochaei S. 2013. Removing nickel and zinc from aqueous environments using modified cocopeat. Int Res J Appl Basic Sci. 4(11):3434-3443. http: //www.irjabs.com/files_site/paperlist/r_1320_130 916130016.pdf.

Hazeri N, Shakeri A, Vlizadeh J, Hashemi E, Motavalizadeh Kakhki A. 2012. Removal of lead (ii) from aqueous solution using cocopeat: an investigation on the isotherm and kinetic. Iran J Chem Chem Eng. 31(3):4550. http://www.ijcce.ac.ir/article_5950_008bd3ee8 0396123299e9f929ecbc067.pdf.

Ho Y, Mckay G. 2000. The kinetics of sorption of divalent metal ions onto sphagnum moss peat. Wat Res. 34:735742. doi:10.1016/S0043-1354(99)00232-8.

Israel DC, Asirot JP. 2002. Mercury pollution due to smallscale gold mining in the Philippines: an economic analysis. Research Paper Series No. 2002.02. Makati City: Philippine Institute for Development Studies. https: //dirp4.pids.gov.ph/ris/rps/pidsrp0202.pdf.

Kaczala F, Marques M, Hogland W. 2009. Lead and vanadium removal from a real industrial wastewater by gravitational settling/sedimentation and sorption onto Pinus sylvestris sawdust. Bioresour Technol. 100:235-243. doi:10.1016/j.biortech.2008.05.055.

Kazemipour M, Ansari M, Tajrobehkar S, Majdzadeh M, HR K. 2008. Removal of lead, cadmium, zinc, and copper from industrial wastewater by carbon developed from walnut, hazelnut, almond, pistachio shell, and apricot stone. J Hazard Mater. 150(2):322-327. doi:10.1016/j.jh azmat.2007.04.118.

Lee B, Rowell R. 2004. Removal of heavy metal ions from aqueous solutions using lignocellulosic fibers. J Nat Fibers. 1(1):97-108. doi:10.1300/J395v01n01_07.

Oboh I, Aluyor E, Audu T. 2009. Biosorption of heavy metal ions from aqueous solutions using a biomaterial. Leonardo J Sci. 14:58-65. http://ljs.academicdirect.o
rg/A14/058_065.pdf.

Ong D. 2010. Removal of heavy metals from single species and composite species aqueous solutions using coco peat as sorbent material [master's thesis]. [Quezon City]: University of the Philippines Diliman. http:// koha.nlp.gov.ph/cgi-bin/koha/opac-ISBDdetail.pl?b $\mathrm{ib}=622583$.

Parcon M. 2010. Equilibrium and kinetic studies on the adsorption of lead and copper in aqueous solution on coco peat [master's thesis]. [Quezon City]: University of the Philippines Diliman. http://koha.nlp.gov.ph/cg i-bin/koha/opac-ISBDdetail.pl?bib=622583.

Perez E, Appel P, Koester-Rasmussen R. 2007. Training of small scale miners and their families in safe handling of mercury during extraction of gold in the Philippines. Improving access to social services: health services and income opportunities for small scale miners and their families. Copenhagen: Geological Survey of Denmark and Greenland, Ministry of the Environment. Danmarks Og Grønlands Geologiske Undersøgelse Rapport 2007/35. http://artisanalmining.org/Repository/01/ The_CASM_Files/CASM_Meetings_International/2 007_Ulaanbaatar_AGM/Presentations/5.3_Breakou t_Environment_technology_\%28incl._PreConf_sessi on\%29/Appel_Philippines_training_report.pdf.

Pingul S. 2010. Efficiency of coco peat in adsorbing Cd (II): evaluation using batch tests [master's thesis]. [Quezon City]: University of the Philippines Diliman. http://ko ha.nlp.gov.ph/cgi-bin/koha/opac-ISBDdetail.pl?bib $=622594$.

Samaniego J, Tanchuling M. 2018. Sedimentation tests of small scale gold mining wastewater. Int J Sci Technol Res. 7(6):73-80. http://www.ijstr.org/final-print/ju ne2018/Sedimentation-Tests-Of-Small-Scale-Gold - Mining-Wastewater-.pdf.

Velasquez-Lopez P, Veiga M, Hall K. 2010. Mercury balance in amalgamation in artisanal and small-scale gold mining: identifying strategies for reducing environmental pollution in portovelo-zaruma, ecuador. J Clean Prod. 18:226-232. doi:10.1016/j.jclepro.2009.10.010.

Vijayaraghavan K, Rangabhashiyam S, Ashokkumar T, Arockiaraj J. 2016. Mono- and multi-component biosorption of lead(ii), cadmium(ii), copper(ii) and nickel(ii) ions onto coco-peat biomass. Sep Sci Technol. 51(17):2725-2733. doi:10.1080/01496395.2016.1212889.

Waskita K, Resurreccion A, Budianta W. 2012. Kinetic and equilibrium studies on the adsorption of pb2+ and $\mathrm{zn} 2+$ from aqueous solution using coco-peat by batch experiment. J Appl Geol. 4(1):29-35. doi:10.22146/jag.7194. 